\title{
SURRENDERING TO TRUST
}

\author{
Alison Dunn, Lecturer in Law, University of Newcastle*
}

\section{CENTRAL LONDON COMMERCIAL ESTATES LTD V KATO KAGAKU CO. LTD (AXA EQUITY AND LAW LIFE ASSURANCE SOCIETY PLC., THIRD PARTY)}

"The search for the true meaning of a statute, especially the Land Registration Act 1925," commented Sedley J. in Central London Commercial Estates Ltd v Kato Kagaku Co. Ltd, 1 "is not the same thing as a search for simplicity." Particularly is this so in the context of the provisions of that Act which concern the acquisition of title by adverse possession. Indeed, the Law Commission in their recent consultative document on registered land expressed the view that far from simplicity, the registered land provisions on adverse possession added a "quite unnecessary layer of complexity". ${ }^{2}$ Eschewing simplicity, it was the search for clarity in the face of uncertainty in this arena which fell upon Sedley $\mathrm{J}$ in Kato Kagaku.

In Kato Kagaku a 94 and a half year lease was entered into by London County Council in 1935 as freeholder, leasing from the 24 June 1934 the south-west wing and the abutting courtyard of Bush House in the Strand, London, to St Clement's Property Co. At all relevant times the freehold and leasehold titles to Bush House were registered. After sub-demising the south-west wing and the building below ground level, but not the abutting courtyard of the property, to the Crown in 1935 for a period of ten days less than the headlease, St Clement's Property Co thereafter passed the headlease to Axa Equity \& Law (Axa) in 1942. In December 1996 Axa surrendered by deed the headlease to the freeholder, who by this time was Central London Commercial Estates Ltd (Central), the plaintiff in the present action. Upon surrender of the headlease by Axa to Central, the Land Registry closed the title to the leasehold and re-registered the freehold of the south-west wing as subject only to the sub-demise in favour of the Crown. The north-west wing of Bush House was owned by the defendant, Kato Kagaku Co Ltd (Kato). For more than twelve years Kato and Kato's predecessors had used the courtyard abutting the northwest wing and, by virtue of adverse possession, the courtyard abutting the south-west wing of Bush House for a paying car park. After the surrender of the headlease by Axa, Central sought possession of the south-west wing courtyard from Kato.

On a hearing of certain preliminary points one principal issue arose. In the context of registered land in England, where leasehold title had been acquired through adverse possession, would surrender of the lease to the lessor by the dispossessed lessee operate so as to defeat the possessory title and allow the lessor an immediate right to possession? Sedley J, sitting as an additional judge of the Chancery Division, rightly approached this issue as turning upon construction of section 75 of the Land

* I am grateful to Dr Alan Dowling for his helpful comments on an earlier draft of this article.

1 [1998] 4 All ER 948, at 959.

2 Land Registration for the Twenty-First Century, Law Com No. 254 (1998), para 10.28 


\section{Northern Ireland Legal Quarterly [Vol. 50, No. 2]}

Registration Act 1925 (LRA). ${ }^{3}$ His ultimate interpretation of that section leaves a marked difference between the operation of limitation in unregistered and registered conveyancing in English law, and raises crucial questions about the nature of the interest which a squatter acquires when registered leasehold land is adversely possessed.

The relativity of rights between a lessor, lessee and a squatter who has dispossessed the lessee has never been fully or satisfactorily resolved either by the English or Irish courts. Few cases concern adverse possession of a leasehold, and even fewer adverse possession of a leasehold in registered land. In unregistered land, the solution accepted by the House of Lords in Fairweather $v$ St. Marylebone Property Co Ltd falls clearly in favour of a lessor. Where a dispossessed lessee surrenders the lease to a lessor in unregistered land, the House of Lords have held by a majority that the lessor has an immediate right to possession against a squatter, even where the adverse possession has occurred for twelve years or more prior to the surrender. This position is based on the premise that the squatter acquires a right to possession but, crucially, the dispossessed lessee retains his estate in the land, albeit shorn of his own right of possession. The estate which remains in the hands of the original lessee allows surrender of the lease on the covenants, and upon surrender the lessor has an immediate right to possession. This is because the squatter's possession "only defeats the rights of those to whom it has been adverse."

The system of registered land with its requirement for registration of proprietors makes the limitation scheme, which hinges upon possession and the automatic extinguishing and acquiring of titles, somewhat more difficult to apply. To that end special provisions are to be found in section 75 of the LRA which, whilst allowing for the Limitation Act 1980 to apply to registered and unregistered land alike, accommodates the limitation scheme to registered land principles. Accordingly, under section 75(2) of the LRA, a squatter who has acquired title by adverse

3 According to section 75 LRA “(1) The Limitation Acts shall apply to registered land in the same manner and to the same extent as those Acts apply to land not registered, except where, if the land were not registered, the estate of the person registered as proprietor would be extinguished, such estate shall not be extinguished but shall be deemed to be held by the proprietor for the time being in trust for the person who, by virtue of the said Acts, has acquired title against any proprietor, but without prejudice to the estates and interests of any other person interested in the land whose estate or interest is not extinguished by those Acts.

(2) Any person claiming to have acquired a title under the Limitation Acts to a registered estate in the land may apply to be registered as proprietor thereof.

(3) The registrar shall, on being satisfied as to the applicant's title, enter the applicant as proprietor either with absolute, good leasehold, qualified, or possessory title, as the case may require, but without prejudice to any estate or interest protected by any entry on the register which may not have been extinguished under the Limitation Acts, and such registration shall, subject as aforesaid, have the same effect as the registration of a first proprietor; but the proprietor or the applicant or any person interested may apply to the court for the determination of any question arising under this section."

4 [1963] AC 510, overruling Walter v Yalden [1902] 2 KB 304. For criticism of Fairweather see Ching Ping Kwan v Lam Island Development Co Ltd [1997] AC 38, Perry v Woodfarm Homes Ltd [1975] IR 104, Wade, "Landlord, Tenant and Squatter" (1962) 78 Law Quarterly Review 541.

5 Per Lord Radcliffe, Fairweather v St Marylebone Property Co Ltd, supra, n 4, at 536. 
possession has the right to apply to become registered as proprietor of that title, and section 75(3) of the LRA empowers the Land Registrar to complete registration of title as is appropriate, with such registration taking the same effect as first registration. ${ }^{6}$ Moreover, where a squatter has succeeded in exercising his right to become the registered leasehold proprietor under section $75(2)$ and (3) of the LRA, following the decision in Spectrum Investments Co v Holmes, ${ }^{7}$ registration provides protection against a lessor's action for possession subsequent to a surrender of the lease by a dispossessed lessee.

Section 75(1) of the LRA is concerned with the situation where the twelve year limitation period has passed but the squatter has not yet exercised his rights under section 75(2). A sometime debated issue, Sedley $\mathbf{J}$ rightly pointed out in Kato Kagaku that construction of section 75(1) remains one of property law's vexed and unresolved questions. ${ }^{8}$ Central to its interpretation is to understand whether the section merely provides the machinery by which principles of limitation applicable to unregistered land can be adapted to suit the registered land régime, or whether the section provides for a different set of principles for limitation in registered land which fundamentally affect the nature of the interest acquired by adverse possession.

The House of Lords in Fairweather had extolled the view that in cases of surrender prior to registration the position under section 75(1) of the LRA should be no different to the position in unregistered land, allowing the lessor to defeat the possessory title of the squatter by an immediate right to possession. This approach construes section 75 as simply an adapting section which provides the necessary materials to paper over the differences between registered and unregistered land. Their view on this point, however, is no more than obiter and against it must be set the general rule put forward in Williams \& Glyn's Bank $v$ Boland, ${ }^{9}$ that whilst the registered land scheme should ordinarily follow the principles applicable in unregistered land, interpretation of the Land Registration Act should be based upon the natural meaning of each section where that meaning is clear.

To ascertain the natural meaning of section $75(1)$ of the LRA, Sedley J took his lead from Browne-Wilkinson J's earlier judgment in Spectrum Investments Co v Holmes that section 75(1) is to be regarded "as creating a specified exception to a general rule that limitation should affect registered and unregistered land similarly". ${ }^{10}$ Whilst Browne-Wilkinson $\mathbf{J}$ in Spectrum had been quick to distinguish and express no decision on the situation represented by facts similar to the present case, that is surrender of a lease before as opposed to after registration under section 75(2), he had construed section 75 on its "clear and unequivocal" terms. ${ }^{11}$ In Kato Kagaku the accepted interpretation of the section on such terms was that whilst the limitation provisions are applicable to registered land as to

${ }^{6}$ Such registration takes place without prejudice to any registered estate or interest not extinguished by the period of limitation.

7 [1981] 1 WLR 221.

8 Supra, n 1, at 950. Earlier Lord Radcliffe in Fairweather, supra, n 4, at 541 expressed his view that the true meaning of section 75(1) was "not at all easy to discover", and that on that occasion it was best "to say as little about it as possible". See also Sir John Pennycuick, Jessamine Investment Co v Schwartz [1978] QB 264, at 275.

9 [1981] AC 487

10 Supra, n 1, at 958.

11 Supra, n 7, at 230, 231. 
unregistered land, whereas in unregistered land a proprietor's estate is extinguished after the limitation period had passed, in registered land the proprietor's estate is not extinguished, but deemed to be held by the proprietor on trust for the adverse possessor. So where leasehold land has been adversely possessed, as by Kato in the present case, on the expiration of twelve years a statutory trust automatically arises by virtue of section 75(1) in favour of the squatter. This has the consequence that, in the words of Sedley $\mathrm{J}:{ }^{12}$

"a squatter on registered land is deprived by section $75(1)$ of his own prescriptive title ('such estate shall not be extinguished') and is furnished instead with the right to acquire and register as his own the usurped leasehold title."

Such a conclusion is found in contradistinction to the accepted position in unregistered land where, as Lord Radcliffe clearly stated in Fairweather, ${ }^{13}$ the squatter's title "is never derived through but arises always in spite of the dispossessed owner".

In arguing against the imposition of a statutory trust in Kato Kagaku, counsel for Central and Axa contended that such a trust was in any event a legal oddity, bearing no relation to a private trust in the general legal understanding of such a term, it merely being a conveyancing device. ${ }^{14}$ Indeed, the House of Lords in Fairweather had earlier questioned whether the mechanism which arose under section 75(1) of the LRA was in fact a trust, being of the view that if it was it would give rise to numerous problems. It is true that the acceptance of this statutory trust under section 75 (1) will have consequences in the context of leasehold title which go beyond the principles of limitation as ordinarily understood, and which lead to a marked divergence in approach between registered and unregistered land. Particularly is this so where a dispossessed lessee attempts to surrender a usurped leasehold interest before the squatter has exercised his rights under section $75(2)$.

In construing section 75(1) and in seeking to provide an answer to the issue of whether surrender by a dispossessed lessee in registered land would allow a lessor an immediate right of possession against a squatter, it was incumbent upon Sedley $\mathbf{J}$ to ascertain the extent of the interest which the statutory trust protects. As noted above, in unregistered land adverse possession against a lessee leads to no more than the shearing of the lessee's right to possession from his leasehold estate. Counsel for Central and Axa both argued that a distinction between title and estate applied equally in registered land, inasmuch as section 75(1) of the LRA only provided an exception to the unregistered land rule where it was a proprietor's estate which had been extinguished. This exception, they argued, would not actually take effect in fact because section 17 of the Limitation Act 1980 only barred title, not estate. ${ }^{15}$ Whilst the precise nature and characteristics of the statutory trust which arises under section $75(1)$ of the LRA were left open by Sedley J, he rejected counsels' argument, finding a distinction between estate and title "meaningless" in the overall framework of the Limitation Acts. The dismissal of such an artificial distinction in this context is surely correct, though it has specific ramifications in the registration scheme. Sedley $\mathbf{J}$ went on to hold that for the purposes of section 75(1) of the LRA there was nothing within its ordinary meaning to suggest that the leasehold or freehold estate adversely

12 Supra, n 1, at 955. Cf Tichborne v Weir (1892) 67 LT 735.

13 Supra, n 4, at 535.

14 Supra, n 1, at 957.

15 Supra, n 1, at 957. 
possessed could be divisible into possessory or other rights. He reasoned that ${ }^{16}$ :

"To split the leasehold interest after twelve years' adverse possession into an element related entirely to the freehold and another related solely to the squatter, as is now known to happen with unregistered land, does not seem to me to marry up with either the purpose or the operation of section 75(1)."

Moreover, since registration under section 75(2) afforded a squatter the entire leasehold interest, Sedley $\mathbf{J}$ felt that the statute itself indicated that section 75(1) should preserve the same and not a lesser interest than that within section $75(2)$.

The consequence of maintaining the indivisibility of an estate under section 75(1) of the LRA, however, is that the interest of which the squatter becomes a beneficiary under the statutory trust is furnished with rights and obligations not readily associated with acquiring possessory title. As Sedley J explained ${ }^{17}$ :

"section 75 lifts the extinguishing effect of the Limitation Act and substitutes a trust of the leasehold interest, benefits and burdens alike, from the moment of extinction of the leasehold title. The squatter becomes entitled, without regard to merits, to be placed in the same relationship with the freeholder as had previously been enjoyed by the leaseholder."

As such, any surrender by a dispossessed lessee in registered land, according to Sedley $\mathrm{J}$, will be ineffective to allow a lessor into possession precisely because the lessee's entire estate is held on trust leaving him with no interest to surrender on his own behalf. This is in line with the general principle nemo dat quod non habet. All that surrender would be effective to do would be to pass trusteeship from the dispossessed lessee to the lessor. Moreover, once the trust has arisen, the squatter has an overriding interest under section 70(1)(f) of the LRA which would bind the lessor upon disposition of the leasehold. ${ }^{18}$

Sedley J's decision on indivisibility of estate has meant that the limitation scheme now provides a squatter of registered land who has not taken the step of registering his title under section 75(2), all the benefits and burdens associated with a lessee's estate, beyond a possessory title, under the protection of a trust. This would seem to include all the dispossessed lessee's covenanted obligations, such as those to pay rent or effect repair. ${ }^{19}$ Taken to its natural extent, it would also include the lessee's liabilities, so enabling the lessor to recover against the squatter redress for any breach of the lease's covenants previously committed by the lessee - perhaps most

6 Supra, n 1, at 959.

17 Supra, n 1, at 959, emphasis added.

18 See sections 23(1)(c) and 69 LRA. The squatter may also have an overriding interest under section 70(1)(g) LRA up to and including when the limitation period is satisfied.

19 This could lead to anomalies. On the facts of Kato Kagaku, Kato had adversely possessed only part of Axa's land - the courtyard to the south-west wing of Bush House. If, as Sedley J held, Axa's entire estate forms the subject matter of the trust, is that simply with regard to the courtyard, or the whole south-west wing? If the latter it would include a reversionary interest in the sub-demise to the Crown and so include an interest in and liability for parts of the property not so directly connected to the courtyard, but which fall within Axa's full estate. 
seriously a lessee's non-payment of rent. ${ }^{20}$ Quite apart from concerns over the resurgence of a 'statutory conveyance' and its associated consequences, ${ }^{21}$ surely it is not the purpose of the scheme of limitation which practises a disinterested even-handedness, indeed a neutrality, in quieting possession between parties to set up a penalty through protection. In the early 1960s Professor Wade had argued that whilst section 75 of the LRA did modify privity between the dispossessed and the dispossessor, the provision was no more than a mechanical device to "preserve continuity of the registered title where otherwise there would have to be rectification of the register". ${ }^{22}$ As such what marks the difference between limitation in registered and unregistered land should be no more than the addition of a device in registered land to achieve ease of application of the limitation principles. However, the operation of section 75(1) of the LRA with its imposition of a trust as interpreted in Kato Kagaku can be seen to go beyond the remit of a tool used to ease the achievement of a particular object as to altering the nature of the object itself.

In view of the fact that Sedley J. held that surrender did not operate to permit a lessor an immediate right to possession and so defeat the title of the squatter, there was no need for him to go on to consider Kato's further submission that a surrender causing defeat would amount to a breach of the trust imposed by section 75(1) of the LRA, and thereby allow a defeated squatter a remedy for breach against the lessee. It is a shame that the purport of this submission could not have been tested by the court, since any analysis of it would surely have challenged the appositeness of applying a trust at all in these circumstances without a full appreciation of the trust's nature, breadth or extent. Kato's submission highlights the many potential problems associated with a section 75(1) LRA trust. For example, as a trustee, and at that most likely a bare trustee, the dispossessed lessee, or a substituted lessor, must ensure that the trust be carried out in a way which does not frustrate the trust's purpose. Whilst the purpose of the trust is presently unclear, one would expect it to concern the preservation and protection of the squatter's interest. This raises immediately the question of the trustee's duty of care in carrying out the trust, which includes a duty not to make an unauthorised profit from the trust and a duty to ensure that the trustee's interests and the interests of the beneficiary do not conflict. ${ }^{23}$ These duties are strictly applied in the law of equity ${ }^{24}$ and possible areas of tension can be easily predicted. For one example one could point to the conflict of interest which may arise, particularly on a question of forfeiture, between a lessor's role as a

20 Protection already exists for a lessor who wishes to seek redress for the dispossessed lessee's parting of possession. It would be considered unusual now for leases not to have within them a covenant against assignment or against parting with possession of the whole or part of the property without the consent of the lessor. For those leases which do contain such a covenant a lessor would have a remedy on the contract against the original lessee, or against the squatter where so bound by the covenants.

21 The notion of a statutory conveyance was laid to rest in England by Tichborne $v$ Weir (1892) 67 LT 735 and in Ireland by O'Connor v Foley [1906] 1 IR 20. In Tichborne Lord Esher, at 737, had emphasised that the effect of the limitation provisions was to extinguish and destroy the title of the dispossessed owner rather than to transfer that title to the squatter.

22 In "Landlord, Tenant and Squatter", supra, n 4, at 558.

23 Bray $v$ Ford [1896] AC 44.

24 See, for example, Keech $v$ Sandford (1726) Sel. Cas. Ch 61, Boardman v Phipps [1967] 2 AC 46, Reading v Att-Gen [1951] AC 507. 
substituted trustee to act in favour of the squatter and the lessor's role as a self-interested landlord.

The paucity of cases in this arena has meant that the trust which is deemed to arise under section 75(1) has yet to be tried and tested. This trust is an enigma and, as already pointed out by a number of commentators, it raises more issues than it ostensibly solves. ${ }^{25}$ The decision of Sedley $\mathbf{J}$ in Kato Kagaku does much the same and one should be wary of an automatic adoption of the case's ratio, reasoning and effect. What is specifically highlighted is that success of the trust device which is used to adapt the limitation scheme with regard to freehold and leasehold land into registered conveyancing in England, is clearly open to debate. This debate is one which Ireland should consider carefully before embracing a similar approach, most particularly because of the greater prevalence in Ireland of possession of leasehold land. ${ }^{26}$

Northern Ireland's adjustment of the limitation provisions into its registered land scheme are provided for in section 53 of the Land Registration Act (Northern Ireland) 1970. This provision allows for the registration of a squatter as proprietor after the expiration of twelve years. $^{27}$ In practice this has meant that registration takes effect on the same folio of the dispossessed owner, ${ }^{28}$ compared with the practice in England where registration of the adverse possessor as proprietor takes effect as first registration. ${ }^{29}$ There is no similar provision in section 53 or more generally in the Land Registration Act (Northern Ireland) 1970 to the English provision in section 75(1) of the LRA, allowing for a trust to arise in the period between the expiration of the twelve years and the exercise of the power by the squatter to apply to be registered as proprietor under section 53(2). Thus, where a dispossessed lessee seeks to surrender the lease to the lessor prior to an application for registration by the squatter the lacuna in the Northern Ireland legislation means that it is unclear what effect, if any, the surrender will have. Disagreement already exists as to the extent to which the provisions of the House of Lords with respect to unregistered land from Fairweather are applicable in Northern Ireland,$^{30}$ but they were distinctly rejected in the Republic of Ireland by the Supreme Court in Perry $v$ Woodfarm Homes Ltd. ${ }^{31}$ Whilst the Supreme Court in Perry agreed with the view of the House of Lords in Fairweather that upon the expiration of twelve years the lease was not destroyed, it disagreed with the view that this allowed the dispossessed lessee to effectively deal with the property and so validly surrender the

25 See in particular, Cooke, "Adverse Possession - Problems of Title in Registered Land" (1994) 14 Legal Studies 1.

26 A point given as one rationale for not adopting the Fairweather approach in the Republic of Ireland: see the comments of Griffin J in Perry $v$ Woodfarm Homes Ltd [1975] IR 104, 129, case discussed infra.

27 The interest of the adverse possessor is also capable of being an overriding interest, see Sch 5, pt I, para 14, Land Registration Act (Northern Ireland) 1970.

28 As to which see Wylie, Irish Land Law (Oxon: Professional Books, $2^{\text {nd }}$ edn., 1986), at 940, Wallace, "Adverse Possession of Registered Land" (1981) 32 NILQ 254, 261.

29 Section 75(3) LRA.

30 Wylie, Irish Land Law (Oxon: Professional Books, $2^{\text {nd }}$ edn., 1986), at 942, $c f$ Wallace, supra $\mathrm{n} 28$, at 261.

31 [1975] IR 104, and see section 49 Registration of Title Act 1964. 


\section{Northern Ireland Legal Quarterly [Vol. 50, No. 2]}

lease to the lessor. ${ }^{32}$ Rather, in Perry the principle nemo dat quod non habet applied with the consequence that the lessor remained bound by the lease for the remainder of the term unless a question of forfeiture arose. ${ }^{33}$

Whilst ostensibly not offering much protection to either the dispossessed lessee who will remain liable on the covenants or the squatter who may suffer forfeiture for a breach of covenants of which he could be unaware, the approach taken in the Republic of Ireland under Perry does seem to be more preferable overall than the artificial imposition of a trust in registered land, a trust whose nature is not only unclear but which also appears from its application in Kato Kagaku to adulterate the principles of limitation. If the trust's primary purpose is to more properly reflect the registered land mirror of title principle then in so doing it should not create fundamental confusion as to the nature of the interest so held. It would be best in absence of any express provision for the imposition of a trust, as is the case in Northern Ireland, to fall back upon first principles ${ }^{34}$ rather than to unleash an animal of indeterminate disposition. The English Law Commission in their most recent consultation paper on registered land have in fact recommended that the trust which arises under section 75(1) LRA be abolished, and that the law of adverse possession as it applies to registered land be "recast" to more properly reflect the scheme's principles of registration of title. ${ }^{35}$ Whilst it would be a shame to wholly lose the utility of possession which is an important feature of both English and Irish land law, the decision in Central London Commercial Estates Ltd v Kato Kagaku Co. Ltd, inasmuch as it highlights the problems of the section 75(1) trust and adverse possession in registered land, does little if not add fuel to the Law Commission's argument.

32 See in particular the judgment of Walsh J, supra, n 31, at 119, and Griffin J, at 130. The Supreme Court accepted the views of Lord Morris of Borth-y-Gest who had given the dissenting judgment in Fairweather.

33 For comment see Wallace, "Adverse Possession of Leaseholds - The Case For Reform" (1975) 10 Irish Jurist (n.s.) 74.

34 For example the effect of estoppel, see O'Connor v Foley [1906] 1 IR 20; Wylie, "Adverse Possession: An Ailing Concept" (1965) 16 NILQ 467, at $485 \mathrm{ff}$. If the lessor accepts a benefit from the squatter (a most obvious example being the payment of rent, but the benefit could derive from an accepted performance of any covenant under the original lease), the lessor must also accept the burden of the interest and will be estopped from denying the title of the squatter. This principle operates in a similar manner to the situation where the grant of an unauthorised tenancy under a lease of mortgaged premises may become authorised, and so binding upon a mortgagee, in circumstances where the mortgagee's acceptance of acts of the unauthorised tenant estops the mortgagee from denying existence of a valid tenancy, see for example Stroud Building Society v Delamont [1960] 1 All ER 749.

35 Land Registration for the Twenty-First Century, Law Com No. 254 (1998), para $2.44,10.19$. 